\title{
Influence of Some Water Physicochemical Parameters on the Distribution of Black Fly (Diptera, Simuliidae) in Some Rivers in Nasarawa State, Nigeria
}

\author{
J. D. C. Tongjura1, G. A. Amuga1, H. B. Mafuyai2 ${ }^{*}$, B. M. Matur ${ }^{3}$, J. O. Olatunwa ${ }^{4}$ \\ ${ }^{1}$ Department of Biological Sciences, Nasarawa State University, Keffi, Nigeria \\ ${ }^{2}$ Department of Zoology, University of Jos, Jos, Nigeria \\ ${ }^{3}$ Department of Biological Sciences, University of Abuja, Abuja, Nigeria \\ ${ }^{4}$ Mission to Support the Helpless, Jos, Nigeria \\ Email: jictongjura@yahoo.com
}

Received 1 April 2015; accepted 19 June 2015; published 23 June 2015

Copyright (C) 2015 by authors and Scientific Research Publishing Inc.

This work is licensed under the Creative Commons Attribution International License (CC BY). http://creativecommons.org/licenses/by/4.0/

(c) (i) Open Access

\begin{abstract}
Changes in the distribution of simuliid species and their disease transmission pattern may occur in response to climatic and environmental factors. Simuliid larvae were prospected in 34 rivers of Nasarawa State from January 2010 to December 2010. A total of 198,420 simuliid larvae collected were found to belong to six species as follows: S. damnosum s.l. (72.13\%), S. adersi $(24.31 \%)$, S. ruficorne $(2.52 \%)$, S. cervicornutum $(0.69 \%)$, S. alcocki $(0.68 \%)$, and $S$. schoutedeni $(0.17 \%)$. The monthly sample indicated continuous breeding throughout the year with peaks in July, August and September. The density of black fly larvae was estimated from samples collected on water plants per $1 \mathbf{d m}^{2}$ of water plant surface. The study showed that both physicochemical and ecological parameters influenced the density of simuliids. Correlation analysis showed a significant relationship between simuliids density and the environmental factors. Data on prevalence and distribution of simuliids in Nasarawa State are sparse and scanty. Therefore, the result of this study provides additional information on the distribution and density of simuliids in Nasarawa State, Nigeria.
\end{abstract}

\section{Keywords}

Distribution, Density, Simuliid, Nasarawa State

\footnotetext{
${ }^{*}$ Corresponding author.
}

How to cite this paper: Tongjura, J.D.C., Amuga, G.A., Mafuyai, H.B., Matur, B.M. and Olatunwa, J.O. (2015) Influence of Some Water Physicochemical Parameters on the Distribution of Black Fly (Diptera, Simuliidae) in Some Rivers in Nasarawa State, Nigeria. Advances in Entomology, 3, 101-110. http://dx.doi.org/10.4236/ae.2015.33012 


\section{Introduction}

There are about 2072 species of black flies in the world today, with 2060 living and 12 extinct [1]. The family simuliidae is worldwide in distribution and is found in most rivers extending from the tropics to the Arctic Circle, only in flowing streams and rivers, even in desert ecosystems and in high polar latitudes, and coral islands [2]. Simuliids are found attached to various substrates in the fresh water streams and exhibit peculiar breeding habitat selection [3]-[6]. Nasarawa State of Nigeria falls within the onchocerciasis belt in the sub-Saharan region [7]. These simuliids are widely distributed in all the Local government areas of Nasarawa State biting and causing discomfort to man.

Simuliids have been reported breeding throughout the year in Florida, and their distribution is favoured by high temperatures [8]. Twenty or more generations have been reported in a year elsewhere in some hot countries due to high and favourable temperatures [9] [10].

Many environmental factors (biotic and abiotic) have been associated with the richness and variation in simuliids species composition. The variations in diversity might originate from differences in environmental factors among sites and niche differences between the different species [11]-[14]. The principal environmental factors affecting simuliids distribution are water temperature, current velocity, $\mathrm{pH}$, stream width and depth, vegetation, characters of stream bed, turbidity, availability of food material and dissolved oxygen concentration [4]. Many of these factors have been used to predict species distribution [15] [16]. Simuliid larvae exploit the organic matter in water for their food needs, hence enriching the lotic region, causing significant effects on species composition, larval density and distribution [4]. However, direct correlation was not found between current velocity and degree of oxygen saturation, suggesting that the relationship of simuliids to current is not determined through the oxygen factor [17].

The size of Simulium pupae depends upon the availability of food material during larval development. When plankton is less abundant (e.g. during drought), pupae are smaller [17]. Physical conditions of the substrata have a pronounced effect in limiting larval distribution. Accumulation of silt and overgrowth by bryophytes compel larval migration, and these conditions occur most readily when the current velocityis slow [18] [19]. Algae have been reported to be a limiting factor anywhere they occurred. Similarly, working independent these authors [17][19] reported similar findings.

Nasarawa State habours different species of simuliids [20], S. alcocki, S. cervicornutum, S. unicornutum, S. adersi, S. hargreavesi Gibbins, and S. damnosum complex. It is [21] difficult to say how substrate influence the density of one simuliid or another. Simuliid larvae are usually found attached to water plants and only rarely to stones. It was confirmed that the densities of S. trifasciatum and S. morsitans were related to river substrate. The larvae of $S$. trifasciatum preferred sand while those of $S$. morsitans preferred courser substrates, such as rubble. Adult simuliid flies are migratory; commonly flying many kilometers from larval breeding sites [22].

Nasarawa State falls along the low altitude zones where temperatures are high throughout the year making it suitable for the flies to produce many generations in a given year. The study on some physicochemical parameters of simuliids breeding water is important for the comprehensive understanding of the distribution and ecology of simuliids. This study was initiated to investigate the distribution and the density of simuliid species including the relationship between biotic and abiotic factors influencing simuliid density and environmental preferences in 34 rivers of Nasarawa State. Frequent sampling was therefore, adopted to determine how species distributions respond to climatic and environmental changes.

\section{Materials and Methods}

\subsection{Study Area}

Nasarawa State is located on latitude $7^{\circ} 45^{\prime}$ and $9^{\circ} 25^{\prime} \mathrm{N}$, longitude $7^{\circ}$ and $9^{\circ} 37^{\prime} \mathrm{E}$ of the Greenwich meridian [23]. It shares boundary with Kaduna State in the north, Plateau State in the east, Taraba and Benue States in the south with Kogi and Federal Capital Territory in the west. The State has a land area of 27137.8 square kilometers with a population of 1,863,275 according to 2006 census. The people of Nasarawa State are mainly farmers; however some are fishermen, hunters, traditional craftsmen and traders. A substantial population of nomads resides in Nasarawa State who supply milk, eggs, butter, hides and skin.

The vegetation type of Nasarawa State is the guinea savanna, which itself is a derivative of the tropical deci- 
duous forest. The vegetation is largely a characteristic of southern guinea savanna and some element of northern guinea savanna with interspersion of thicket grassland, tree savanna, woodlands or gallery forest along the valleys. It is also called woodland savanna or parkland savanna [24].

This study was conducted in eight [8] local government areas (L.G.A.) of Nasarawa State. Selection of rivers was based on proportional stratified random sampling from the southern, northern and western zones in the state. Three LGAs (Lafia, Obi, Doma) were selected from the southern zone. Two L.G.As (Akwanga and Nasarawa Eggon) from the northern zone and three LGAs (Keffi, Kokona and Toto) were selected from the western zone (Figure 1).

\subsection{Study Sites}

The rivers from selected L.G.As. of Nasarawa state were divided into temporary and permanent rivers for the purpose of this study. Sampling sites were chosen from each river and rivers were divided into, shaded or forested or open land. Human activities around the river e.g. farming, fishing, washing, bathing, block making or mechanic workshop. Foot paths linking villages across the rivers were also noted. Commercial and other activities around the rivers were noted. The river bed substratum was divided into mud, sand and rubble.

\section{Sampling of Simullid Larvae and Pupae}

Aquatic stages of simuliids were sampled from 34 rivers covering 8 Local government areas in Nasarawa State. The sampling locations were selected based on rivers crossing only the major roads. Larvae and pupae of simuliids were sampled from all available substrates found in the habitat every month from January to December 2010.

Immature stages of simuliids were found in running water at rapids and rivulets attached to any fixed submerged surface substrates such as water plants, trailing roots and branches and leaves, stones, inclined rock surfaces, cans, bottles, plastics and logs of wood. The immature stages were pick using gold plated fine entomological pins into bijou bottles containing ice cold 1:3 glacial acetic acid and ethanol (carnoys solution) in ice chest. The content was renewed before leaving the river and change before driving away and finally changes again in the laboratory. This is to ensure that water is completely drained away for good preservation. The larvae and pupae were preserved in 1:3 glacial acetic acid and ethanol solution for morphological identifications in the laboratory. Standard procedures were used for morphological identification of simuliids [20].

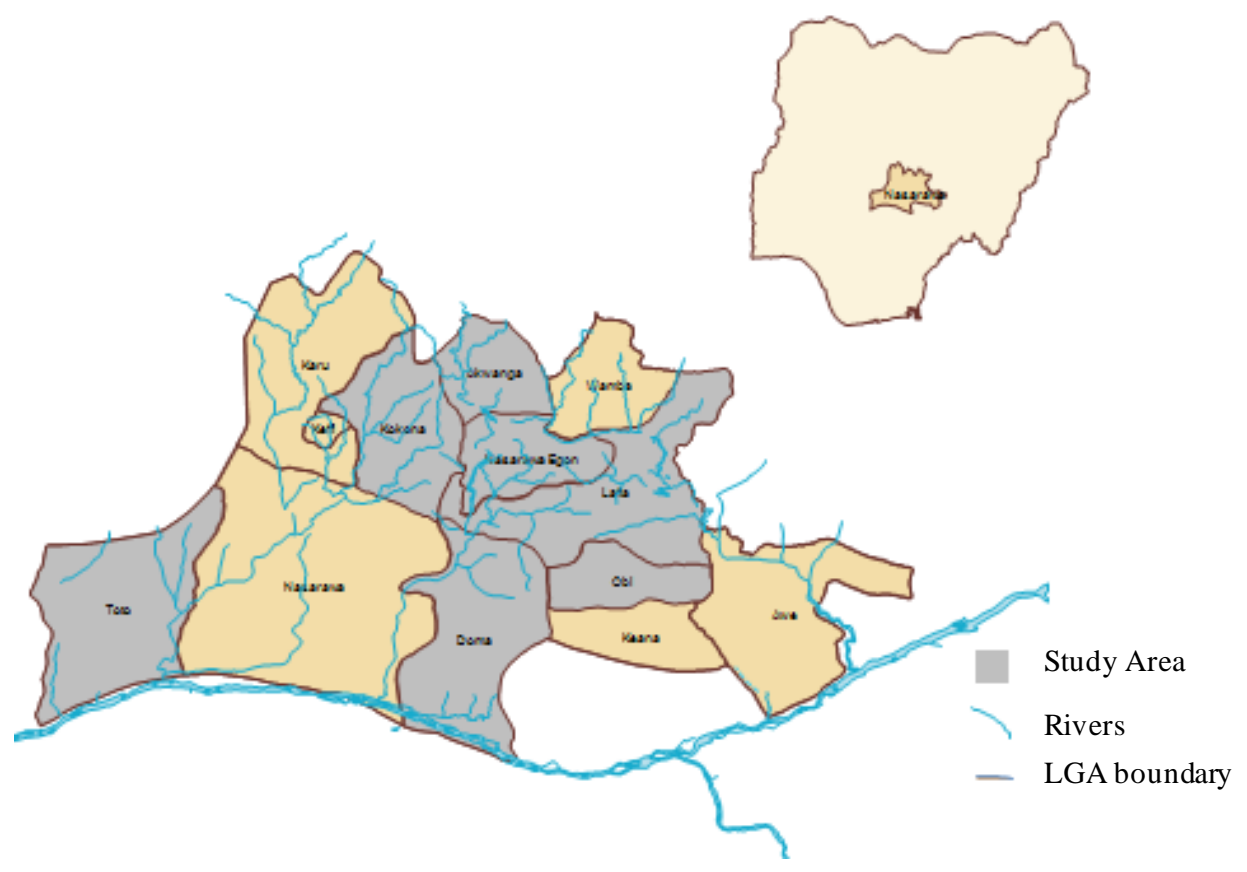

Figure 1. Map of Nasarawa State (Nigeria insert) showing the study area. 


\subsection{Determination of Physicochemical Parameters}

Water samples were collected from the 34 rivers (in $250 \mathrm{ml}$ beaker) and analyze using digital Hanna instrument model HI98129. Water parameters such as $\mathrm{p}^{\mathrm{H}}$, water temperature, conductivity and total dissolve substances were measured.

\subsection{Determination of Ecological Factors}

Standard sampling protocol for measuring width and depth of the river, water current velocity and river bed bottom were followed [5] [15] [25].

\subsection{Data Analysis}

Data analysis was carried out to determine the relationship between simuliids density and each water parameter using correlation analysis to determine the fitness for the presence of different species of simuliid. Principal component analysis (PCA) followed by Varimax rotation were used to collapse water parameters and physicochemical parameters into smaller number of statistically independent principal components to determine their association with the simuliids distribution and density. Simuliids densities among the various locations in the L.G.As and rivers were compared using one way ANOVA.

\section{Results}

Simuliids sampled in Nasarawa State revealed six species as shown on Table 1. A total of 198,420 simuliid larvae were sampled comprising S. damnosum s.l. 143,125 (72.13\%), S. alcocki 1358 (0.68\%), S. adersi 47,238 (24.31\%), S. ruficorne 5008 (2.52), S. schoutedeni 331 (0.17) and S. cervicornutum. All but 2 of the 34 rivers prospected were found to habour simuliids larvae with high densities in rivers Ando, NSUK, Bakin Anini, Mile-5 and Ubbe (Figure 2) The monthly density shows that simuliids breed all year round in Nasarawa State Nigeria but with peaks in the months of July (16.30\%), August (35.09\%) and September (29.52\%) as seen in Figure 3.

Seven physicochemical parameters were analyzed and their effect on the breeding pattern of simuliids determined (Table 2). Seven physicochemical parameters were analyzed and their effect on the breeding pattern of simuliids determined. The result of the correlation coefficient analysis differ significantly as follows -0.136 (temperature), 0.402 (Velocity), 0.360 (width), -0.053 (conductivity), -0.146 (total dissolve substances), 0.146 $\left(\mathrm{p}^{\mathrm{H}}\right),-0.096$ (oxygen saturation) for all the rivers. The difference in density of simuliids among the various locations in the L.G.As was statistically significant $(\mathrm{F}=2.443, \mathrm{df}=7, \mathrm{p}<0.05)$. Similarly the density of simuliids within the various rivers was statistically significant $(\mathrm{F}=4.160, \mathrm{df}=33, \mathrm{p}<0.001)$. At least five principal components have Eigen value $>1$ and accounted for $65.73 \%$ of variation. Simuliid density was associated with L.G.A, river, conductivity, $\mathrm{p}^{\mathrm{H}}$ and total dissolve substances in the study locations.

Ecological survey revealed that some species of simuliids preferred certain rivers and had preference for

Table 1. Black fly species found in Nasarawa State, Nigeria.

\begin{tabular}{ccc}
\hline Species & No. sampled & Percentage (\%) \\
\hline S. damnosum & 143,125 & 72.13 \\
S. alcocki & 1358 & 0.68 \\
S. adersi & 47,238 & 24.31 \\
S. ruficorne & 5008 & 2.52 \\
S. schoutedeni & 331 & 0.17 \\
S. cervicornutum & 1360 & 0.69 \\
S. damnosum & 143,125 & 72.13 \\
Total & 198,420 & $100 \%$ \\
\hline
\end{tabular}




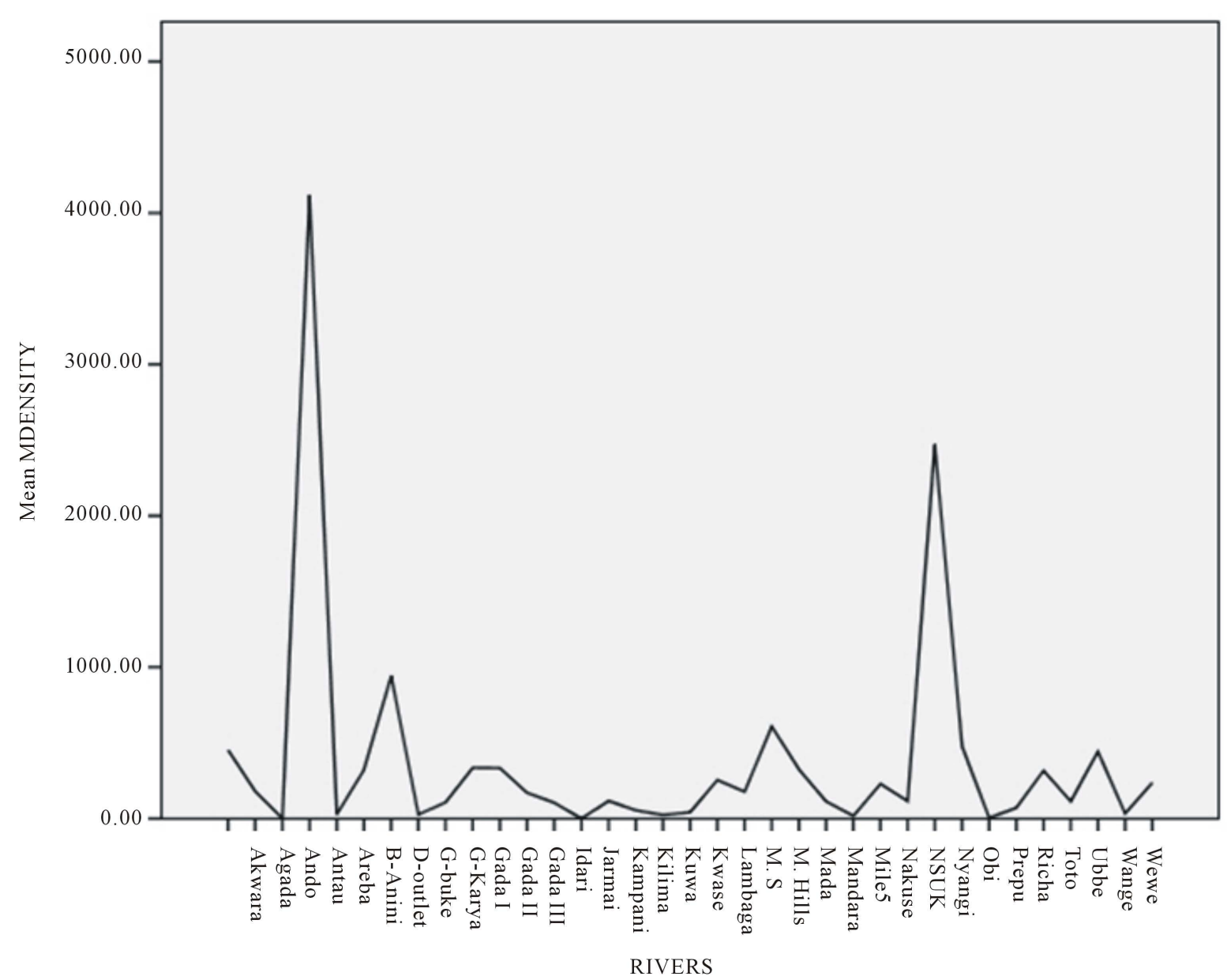

Figure 2. Frequency of simuliid larvae according to the rivers in Nasarawa State, Nigeria.

certain types of substrates and substratum irrespective of the river width and depth at which larvae were found (Table 3).

\section{Discussion}

Rivers in Nasarawa State are two categories permanent or temporary river. Permanent rivers supported all year round breeding. The present investigation has tried to give a detailed and comprehensive report on the prevalence of simuliid species in relationship to various physicochemical water parameters across 34 rivers in Nasarawa State. S. damnosum s.l. constitutes the most common and the most spread species recorded in almost all the rivers investigated. A total of six species recorded earlier [20] comprised of S. alcoki, (river Fa) S. cervicornutum, (rivers Mayel and Mada) S. unicornutum, (river Fa) S. adersi, (rivers Uke, Mile 5, Kama, Farin ruwa) S. hargreavesi (rivers Kam, Fa and Fariinb) and S. damnosum (rivers Uke, Keffi, Mada, Mayel, Sherigiya) in very few rivers. However, the presence of S. unicornutum and S. hargreavesi reported by Crosskey in 1960 where absent in this present investigation.

Of the 34 rivers investigated for simuliid species only 2 rivers (Idari and Agada) did not record any species. Simuliids were absent probably because the rivers have sandy and muddy bottoms and some areas are swampy and therefore, lack strong water flow. It was observed that more than one species of simuliid larvae coexists in the same river within the same microhabitat.

It was earlier reported that the distribution of immature stages of simuliids is influenced by rainfall [19] which causes increase in velocity and nutrient level of the rivers, reducing algae population with increase in larval density. This could be possible reason why simuliids were absent from two rivers due to seasonal fluctuation and complete drying of the rivers. 


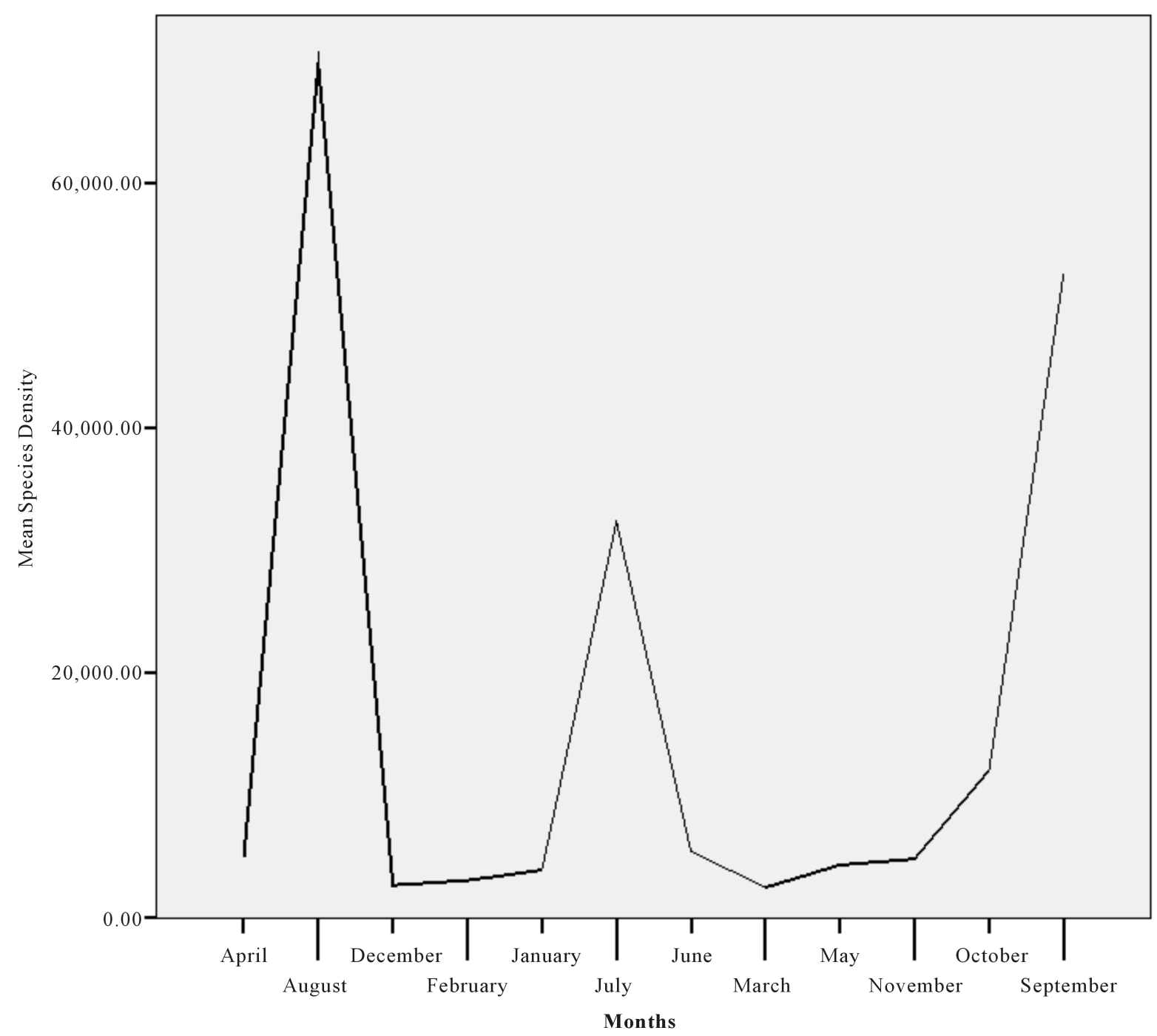

Figure 3. Monthly frequency of simulliids from January to December 2010.

The simuliid immature stages are usually found attached to trailing roots, leaves, sticks, stems, stone surfaces, twigs and grasses which are usually about $5 \mathrm{~cm}$ below the water surface [6] [21]. This study recorded a maximum of only two simuliid species per river within the sampling period. It was noted that some rivers support more simuliid species than others due to difference in physicochemical parameters and substrates preference. This concurs with earlier reports that the overall river health is important for the distribution and richness of simuliid species with biotic interactions acting as primary determinants of species diversity [26] [27]. Freshwater ecologist believe that in addition to certain measurable water variables, there are other parameters which either singly or in combination with each other limit the proliferation of pre-mature stages of simuliids in the breeding habitat [5].

The prevalence of aquatic stages of simuliids in rivers acts as biological indicator of the river's health, which is often considered analogous to human health [28] [29]. The presence of simuliids species in all but two rivers in Nasarawa State is an indication that the streams are not yet polluted by human activities.

In this study physicochemical parameters including $\mathrm{pH}$, conductivity, total dissolved substances, width, velocity, oxygen concentration and temperature influence in various ways the simuliid density and distribution in rivers. Each species of simuliid prefers different physicochemical parameters which are specific for a particular species [6]. However, simuliid species as a whole cannot be considered as a suitable indicator of the streams water quality. The presences of other aquatic organism are also important. 
Table 2. Physicochemical parameters and density of simuliids in rivers in Nasarawa State.

\begin{tabular}{|c|c|c|c|c|c|c|c|c|}
\hline Rivers & pH & $\begin{array}{c}\text { Conductivity } \\
(\mu \mathrm{s})\end{array}$ & $\begin{array}{c}\text { Dissolved } \\
\text { Substances } \\
\text { (ppm) }\end{array}$ & $\begin{array}{l}\text { Width } \\
\text { (m) }\end{array}$ & $\begin{array}{c}\text { Temperature } \\
\left.\text { ( }{ }^{\circ} \mathrm{C}\right)\end{array}$ & $\begin{array}{c}\text { Velocity } \\
(\mathrm{m} / \mathrm{s})\end{array}$ & $\begin{array}{l}\text { Oxygen } \\
\text { Saturation } \\
(\mathrm{mg} / \mathrm{l})\end{array}$ & $\begin{array}{c}\text { Simullids } \\
\text { (immature } \\
\text { stages) }\end{array}$ \\
\hline Mada-Hills & 7.42 & 352.42 & 173.75 & 11.5 & 28.59 & 0.11 & 9.49 & 1303 \\
\hline Mada & 7.56 & 69 & 34.75 & 443.8 & 28.53 & 0.13 & 9.97 & 8257 \\
\hline Richa & 6.06 & 31.58 & 518.8 & 4.6 & 29.26 & 0.1 & 9.52 & 9767 \\
\hline Mada-Station & 7.69 & 113.42 & 57.7 & 476 & 30.13 & 0.21 & 9.20 & 29,028 \\
\hline Wewe & 7.25 & 109.67 & 61.33 & 15.7 & 29.37 & 0.15 & 9.15 & 5321 \\
\hline Kwase & 7.23 & 57.17 & 26.75 & 13.2 & 28.92 & 0.13 & 8.27 & 5054 \\
\hline Ubbe & 7.32 & 99.83 & 43.83 & 12.6 & 28.65 & 0.1 & 9.56 & 5321 \\
\hline Lambaga & 7.6 & 50.5 & 34.8 & 7.3 & 30.31 & 0.12 & 8.38 & 3016 \\
\hline GadaI & 7.48 & 56.1 & 28.4 & 10.5 & 30.37 & 0.13 & 9.29 & 4009 \\
\hline GadaII & 743 & 50.2 & 25.1 & 8.6 & 30.48 & 0.1 & 8.89 & 2046 \\
\hline GadaIII & 7.59 & 46.4 & 26.3 & 24.6 & 30.29 & 0.13 & 9.00 & 1254 \\
\hline Kuwa & 7.2 & 74.75 & 36.42 & 7.9 & 29.82 & 0.14 & 9.72 & 829 \\
\hline Toto & 7.07 & 194 & 97.75 & 10.5 & 30.09 & 0.13 & 9.57 & 1360 \\
\hline Nyangi & 7.52 & 97.33 & 48.83 & 56 & 29 & 0.16 & 9.97 & 5748 \\
\hline GudunKarya & 7.46 & 138.08 & 63.58 & 7.6 & 28.13 & 0.14 & 9.56 & 4025 \\
\hline Nakuse & 7.26 & 725.5 & 299.33 & 6.4 & 28.9 & 0.11 & 9.45 & 1381 \\
\hline Gadabuke & 7.53 & 272.5 & 131.5 & 13.5 & 29.24 & 0.12 & 9.97 & 1276 \\
\hline Areba & 7.53 & 83.5 & 41.42 & 13.9 & 29.43 & 0.12 & 9.56 & 5969 \\
\hline Angwan-Kwara & 7.6 & 257 & 122.92 & 3.2 & 28.93 & 0.13 & 9.78 & 2153 \\
\hline NSUK & 7.42 & 379.17 & 136.5 & 1.4 & 28.98 & 0.16 & 9.62 & 29,682 \\
\hline Antau & 7.5 & 324 & 137.25 & 21 & 28.64 & 0.1 & 9.49 & 329 \\
\hline Mile-5 & 7.54 & 58.42 & 30.92 & 226 & 28.82 & 0.18 & 9.53 & 7937 \\
\hline Jarmai & 7.32 & 96.88 & 54.13 & 3.7 & 29.38 & 0.09 & 9.53 & 1400 \\
\hline Ando & 7.51 & 67.42 & 33.92 & 48 & 29.44 & 0.13 & 9.09 & 49,434 \\
\hline Bakin-Anini & 7.55 & 75.17 & 37.25 & 12.2 & 29.76 & 0.11 & 8.96 & 11,325 \\
\hline Kampani & 7.35 & 74.25 & 36.75 & 9.6 & 29.77 & 0.12 & 9.52 & 648 \\
\hline Mandara & 7.37 & 112.25 & 51.92 & 12.3 & 30.08 & 0.12 & 9.33 & 214 \\
\hline Dam-outlet & 7.49 & 82.33 & 41.25 & 17.8 & 30.48 & 0.14 & 9.30 & 320 \\
\hline Prepu & 7.28 & 145.92 & 74.25 & 2.3 & 30.55 & 0.15 & 9.94 & 281 \\
\hline Wange & 7.16 & 135.92 & 107.33 & 8.3 & 30.26 & 0.14 & 9.85 & 392 \\
\hline Kilima & 7.17 & 510.92 & 232.33 & 4.7 & 30.1 & 0.11 & 9.53 & 283 \\
\hline Obi & 7.18 & 92.75 & 44.83 & 3.5 & 30.28 & 0.11 & 9.34 & 58 \\
\hline
\end{tabular}




\section{J. D. C. Tongjura et al.}

Table 3. Ecological factors and simuliid density in rivers of Nasarawa State.

\begin{tabular}{|c|c|c|c|c|c|c|}
\hline Rivers & $\begin{array}{l}\text { Width } \\
\text { (m) }\end{array}$ & Simuliid species & $\begin{array}{l}\text { Species } \\
\text { density }\end{array}$ & Substratum & Substrates & $\begin{array}{l}\text { Algae } \\
\text { growth }\end{array}$ \\
\hline Mada- Hills & 11.5 & S. damnosum & 3903 & Rubble & both dry and wet leaves, roots, rock & Absent \\
\hline \multirow[t]{2}{*}{ Mada } & 443.8 & S. alcoki & 1358 & Rubble & stones, grasses, sticks and stems & Absent \\
\hline & & S. damnosum & 6849 & & & \\
\hline \multirow[t]{2}{*}{ Richa } & 4.6 & S. ruficorne & 3804 & Rubble & both dry and wet leaves, grasses & Absent \\
\hline & & S. damnosum & 5963 & & & \\
\hline \multirow[t]{2}{*}{ Mada-Station } & 476 & S. adersi & 7289 & Rubble & $\begin{array}{l}\text { both dry and wet leaves, roots, rock } \\
\text { surfaces, stones, grasses, sticks }\end{array}$ & Absent \\
\hline & & S. damnosum & 21,689 & & & \\
\hline Wewe & 15.7 & S. damnosum & 2848 & Rubble & both dry and wet leaves, grasses & Absent \\
\hline Kwase & 13.2 & S. damnosum & 3054 & Rubble & \multirow{3}{*}{$\begin{array}{c}\text { both dry and wet leaves, roots, grasses both } \\
\text { dry, sticks }\end{array}$} & Absent \\
\hline Ubbe & 12.6 & S. damnosum & 5321 & Rubble & & Absent \\
\hline \multirow[t]{2}{*}{ Lambaga } & 7.3 & S. damnosum & 2129 & Rubble & & Absent \\
\hline & & S. adersi & 887 & & & \\
\hline Gada I & 10.5 & S. damnosum & 4009 & Rubble & \multirow{2}{*}{$\begin{array}{l}\text { both dry and wet leaves, both dry and wet } \\
\text { leaves, grasses, sticks, stems }\end{array}$} & Absent \\
\hline Gada II & 8.6 & S. damnosum & 2146 & Rubble & & Absent \\
\hline Gada III & 24.6 & S. damnosum & 1254 & Rubble & & Absent \\
\hline \multirow[t]{2}{*}{ Kuwa } & 7.9 & S. ruficorne & 498 & Sand & dry and wet leaves & Absent \\
\hline & & S. schoutedeni & 331 & & & \\
\hline Toto & 10.5 & S. cervicornutum & 1360 & Sand & dry bamboo leaves, wet and dry grasses & Absent \\
\hline Nyangi & 56 & S. damnosum & 5748 & Rubble & \multirow{3}{*}{$\begin{array}{l}\text { both dry and wet leaves, roots, rock } \\
\text { surfaces, stones, grasses, sticks and stems }\end{array}$} & Absent \\
\hline Gudun-Karya & 7.6 & S. damnosum & 4025 & Rubble & & Absent \\
\hline Nakuse & 6.4 & S. damnosum & 1381 & Rubble & & Absent \\
\hline Gadabuke & 13.5 & S. adersi & 1276 & Rubble & leaves and grasses & Absent \\
\hline \multirow[t]{2}{*}{ Areba } & 13.9 & S. damnosum & 3854 & Rubble & both dry and wet leaves & Absent \\
\hline & & S. adersi & 2115 & & & \\
\hline Angwan-Kwara & 3.2 & S. damnosum & 2153 & Rubble & dry and wet grasses, stones & Present \\
\hline NSUK & 1.4 & S. damnosum & 29,655 & Mud & dry and wet grasses and sticks & Absent \\
\hline Antau & 21 & S. damnosum & 329 & Sand & dry and wet grasses and sticks & present \\
\hline Mile-5 & 226 & S. damnosum & 2744 & Rubble & & Absent \\
\hline & & S. adersi & 5193 & & \multirow{3}{*}{$\begin{array}{l}\text { Both dry and wet leaves, roots, rock } \\
\text { surfaces, stones, grasses and stems } \\
\text { both dry and wet leaves, }\end{array}$} & \\
\hline Jarmai & 3.7 & S. damnosum & 1400 & Rubble & & Absent \\
\hline Ando & 48 & S. adersi & 49434 & Rubble & & Absent \\
\hline Bakin-Anini & 12.2 & S. damnosum & 11,325 & Sand & dry and wet grasses and sticks & Absent \\
\hline Kampani & 9.6 & S. ruficorne & 648 & Sand & dry and wet grasses & Absent \\
\hline Mandara & 12.3 & S. damnosum & 214 & Sand & dry and wet grasses and sticks & Absent \\
\hline Dam-outlet & 17.8 & S. damnosum & 320 & Rubble & stones, dry and wet grasses and sticks & Absent \\
\hline \multirow[t]{2}{*}{ Prepu } & 2.3 & S. damnosum & 850 & Sand & Stems, dry leaves & Present \\
\hline & & S. adersi & 431 & & & \\
\hline Wange & 8.3 & S. adersi & 392 & Sand & dry and wet grasses and sticks & Present \\
\hline Kilima & 4.7 & S. damnosum & 283 & Sand & dry and wet grasses and sticks & Present \\
\hline Obi & 3.5 & S. ruficorne & 58 & Mud & dry and wet grasses and sticks & Absent \\
\hline
\end{tabular}


It is to be noted that while some of the rivers were temporary and dry up completely, others were perennial and supported breeding of simuliid larvae all year round. It was observed that breeding that was reduced to a few sites in the dry season extended very quickly over larger areas of potential breeding in wet season as they become submerged. This explains the fact that simuliids were capable of long distance movement. They have been reported to fly from 10 to $400 \mathrm{~km}$ away from their breeding sites [22].

The density of simuliids larvae was estimated from samples collected on water plants per $1 \mathrm{dm}^{2}$ of water plant surface. The observation of increase in population density of simuliid larvae in the months of July, August and September in this study differs from the all year breeding reported in Florida [8].

Previous reports have it that high temperature favours early completion of life cycle, resulting in many generations in a given year. Twenty or more generations has been reported in a year in some hot countries due to high and favourable temperatures [9] [10]. Apart from high temperatures other biological and physical factors play critical roles. Reports revealed that plants substrate play key role in larvae attachment. This explains the reason why simuliid larvae found on different substrates in the water showed affinity for particular types of plant species. They show preference to plants in the Family - Poaceae, It was observed that larvae were usually found about $5 \mathrm{~cm}$ to $10 \mathrm{~cm}$ below the water surface attached to these substrates.

The presence of algae was found to limit larvae density even on the preferred plants especially in the dry season. Algae colonization of plant surfaces was high in rivers Kilima and Wange in Lafia LGA and river Prepu in Doma LGA. Algae are not likely unconnected to larval migration and these conditions occurred most readily when the water current velocity is slow giving room for algal bloom. This condition was observed between January and June during the dry season when water level was low. This concurs with other reports [7] [18] [19]. Three types of river substrata were determined in the study sites: sand, rubble and mud. The difference in substratum did not appear to regulate the species of simuliid larvae in a particular river in Nasarawa State.

Correlation analysis between the width of the river and the mean density of simuliid larvae in both temporary and permanent rivers showed a significant relationship, $r=0.816$ and $r=-0.201$ respectively. This signified that black fly can breed in both small and large rivers in Nasarawa State. Water current velocity varies from 0.012 $\mathrm{m} / \mathrm{s}$ to $0.702 \mathrm{~m} / \mathrm{s}$ in the study sites. Correlation analysis revealed a significant relationship between water current velocity and the density of black fly in the rivers. This supports earlier reports that black flies bred in fast moving streams and they preferred water current velocities of $0.7-2 \mathrm{~m} \cdot \mathrm{s}^{-1}$ and $0.1-2.5 \mathrm{~m} \cdot \mathrm{s}^{-1}$ [10] [21].

\section{Conclusion}

The breeding of simuliid larvae in both dry and wet season is an indication of serious risk to man and his animals in Nasarawa State which is known for subsistent agricultural (farming, poultry production, cattle rearing and fishing). The dominance of $S$. damnosum complex, the vector of human onchocerciasis, in most rivers in Nasarawa State presents potential risk for the area. This is a threat not only to the meat industry which is not enough to feed the ever rising population of Nigerians but also to tourism industry which government is trying to promote. The ability of the insect vector to fly over $400 \mathrm{~km}$ from their breeding sites poses a threat to the neighboring States of Benue, Plateau, Taraba, Kaduna and the Federal Capital territory, Abuja, giving the fact that most of the people are rural farmers living in close proximity to the rivers.

\section{References}

[1] Adler, P.H. and Crosskey, R.W. (2009) World Black Flies (Diptera: Simuliidae): A Comprehensive Revision of the Taxonomic and Geographical Inventory.

[2] Doreen, W. (2006) Taxonomy, Ecology and Biology of Black Flies (Diptera: Simuliidae). Proceedings of the International Symposium on Simuliidae, Berlin, 2004. Studia Dipterological Supplement, 14.

[3] Malmqvist, B., Zhang, Y. and Adler, P.H. (1999) Diversity, Distribution and Larval Habitats of North Swedish Blackflies (Diptera: Simuliidae). Freshwater Biology, 42, 301-314. http://dx.doi.org/10.1046/j.1365-2427.1999.444497.x

[4] Hamada, N., McCreadie, J.W. and Adler, P.H. (2002) Species Richness and Spatial Distributions of Black Flies (Diptera: Simuliidae) among Streams of Central Amazonia, Brazil. Freshwater Biology, 47, 31-40. http://dx.doi.org/10.1046/j.1365-2427.2002.00778.x

[5] McCreadie, J.W., Adler, P.H. and Hamada, N. (2005) Patterns of Species Richness for Black Flies (Diptera: Simuliidae) in the Nearctic and Neotropical Regions. Ecological Entomologia, 30, 201-209.

[6] Rabha, B., Dhiman, S., Sunil, Y.K., Hazarika, S., Bhola, R.K. and Veer, V. (2013) Influence of Water Physicochemical Characteristics on Simuliidae (Diptera) Prevalence in Some Streams in Meghagaga, India. Journal of Vector Borne 
Diseases, 332, 5731-5738.

[7] World Health Organization (1995) Onchocerciasis and Its Control. Fourth Report of the Expert committee on Onchocerciasis, WHO Technical Report Series NO. 852, 156.

[8] Butler, J.F. and Hogsette, J.A., (2007) University of Florida, USDA-ARS Publication Number EENY-30.

[9] Drees, B.M. and John, J. (2008) Field Guide to Texas Insects. Gulf Publishing Company, Houston.

[10] Nelder, M.P., Beard, C.E., Adler, P.H., Kim, S.K. and McCreadie, J.W. (2006) Harpellalesmycota: Trichomycetes Associated with Black Flies (Diptera: Simullidae). World Review and Synthesis of Their Ecology and Taxonomy. Fungal Diversity, 22, 121-169.

[11] Legendre, P., Bocard, D. and Peres-Neto, P.R. (2005) Analyzing Beta Diversity: Partitioning the Spatial Variation of Community Composition Data. Ecological Monograph, 75, 435-450. http://dx.doi.org/10.1890/05-0549

[12] Tuomisto, P. and Ruokolainen, K. (2006) Analyzing or Explaining Beta Diversity? Understanding the Targets of Different Methods of Analysis. Ecology, 87, 2697-2708. http://dx.doi.org/10.1890/0012-9658(2006)87[2697:AOEBDU]2.0.CO;2

[13] Landeiro, V.L., Pepinelli, M. and Hamada, N. (2009) Species Richness and Distribution of Black Flies (Diptera: Simuliidae) in the Chapada Diamantina Region, Bahia, Brazil. Neotropical Entomology, 38, 332-339. http://dx.doi.org/10.1590/S1519-566X2009000300006

[14] Pachon, R.T. and Walton, W.E. (2011) Seasonal Occurrence of Black Flies (Diptrea: Simuliidae) in a Desert Stream Receiving Trout Farm Effluent. Journal of Vector Ecology, 36, 187-196. http://dx.doi.org/10.1111/j.1948-7134.2011.00156.x

[15] McCreadie, J.W., Adler, P.H., Grillet, M.E. and Hamada, N. (2006) Sampling and Statistics in Understanding Distributions of Black Fly Larvae (Diptera: Simuliidae). Acta Entomologica Serbica, 591, 89-96.

[16] IIIesova, D., Halgos, J. and Krno, I. (2008) Black Fly Assemblages (Diptera: Simuliidae) of the Carpathian River: Habitat Characteristics, Longitudinal Zonation and Eutrophication. Hydrobiologia, 598, 163-174. http://dx.doi.org/10.1007/s10750-007-9148-4

[17] Zahar, A.R. (1955) Ecology and the Distribution of Black-Flies (Simuliidae) in South-East Scotland. Journal of Animal Ecology, 20, 33-62. http://dx.doi.org/10.2307/1643

[18] Crosskey, R.W. (1990) The National History of Blackflies. British Museum of Natural History, London.

[19] Opoku, A.A. (2006) The Ecology and Biting Activity of Blackflies (Simuliidae) and the Prevalence of Onchocerciasis in an Agricultural Community in Ghana. West African Journal of Applied Ecology, 9, 1-7.

[20] Crosskey, R.W. (1960) A Taxonomic Study of the Larvae of West African Simuliidae (Diptera: Nemcera) with Comments on the Morphology of the Larval Black Fly Head. Bulletin of the British Museum (Natural History): Series Entomology, No. 10, 74.

[21] Bernotiene, R. (2006) On the Distribution of Blackfly Larvae (Diptera, Simuliidae) in Different Rivers in Lithuania. Studia Dipterologica, 14, 19-25.

[22] Cranshaw, W.S., Peairs, F.B. and Kondratieff, B. (2010) Colorado State University Extension, USA.

[23] Akwa, V.L., Binbol, N.L., Samaila, K.I. and Marcus, N.D. (2007) Geographical Perspective on Nasarawa State. Pub. Onavi, Keffi.

[24] Peter, M.A., Mohammed, A.M. and Patrick, A.O. (2007) Vegetation and Forest Resources. In: Geographical Perspective on Nasarawa State, A Publication of the Department of Geography, Nasarawa State University, Keffi. Pub. Onaivi, Nasarawa State, Nigeria, 61-66.

[25] McCreadie, J.W. and Adler, P.H. (1998) Scale, Time, Space, and Predictability: Species Distributions of Preimaginal Black Flies (Diptera: Simuliidae). Oecologia, 114, 79-92. http://dx.doi.org/10.1007/s004420050423

[26] Bergon, M., Harer, J.L. and Townsend, C.R. (1996) Ecology: Individuals, Populations and Communities. 3rd Edition, Blackwell Science Ltd., Oxford.

[27] Bergon, M., Townsend, C.R. and Harper, J.L. (2006) Ecology: From Individual to Ecosystems. Blackwell Publication, Victoria, Australia, 738.

[28] Resh, V.H., Norris, R.H. and Barbour, M.T. (1995) Design and Implementation of Rapid Assessment Approaches for Water Resource Monitoring Using Benthic Macro Invertebrates. Australian Journal of Ecology, 20, 108-121. http://dx.doi.org/10.1111/j.1442-9993.1995.tb00525.x

[29] Carlsson, G. (1967) Environmental Factors Influencing Black Fly Populations. Bulletin of World Health Organization, 37, 139-150. 